\title{
Sensitivity and prognostic value of thyroid transcription factor-1 and napsin $A$ in primary adenocarcinoma of the lung
}

\author{
Patryk Kraiński ${ }^{1}$, Piotr J. Skrzypczak², Katarzyna Iwanik ${ }^{1}$, Monika Rozmiarek², Agnieszka Górna ${ }^{3}$, \\ Andrzej Kluk ${ }^{1}$, Paweł Kosikowski ${ }^{1}$, Maciej Bryl ${ }^{4}$, Mariusz Kasprzyk ${ }^{2}$, Aldona Woźniak ${ }^{1}$ \\ ${ }^{1}$ Department of Thoracic Surgery, Wielkopolska Center of Pulmonology and Thoracic Surgery, Poznan University of Medical \\ Sciences, Poznan, Poland \\ 2Department of Clinical Pathology, Heliodor Święcicki Clinical Hospital of Poznan University of Medical Sciences, Poznan, \\ Poland \\ ${ }^{3}$ Department of Clinical Oncology, Wielkopolska Centre for Pulmonology and Thoracic Surgery, Poznan, Poland \\ ${ }^{4}$ Department of Bioinformatics and Computational Biology, Poznan University of Medical Sciences, Heliodor Święcicki Clinical \\ Hospital of Poznan University of Medical Sciences, Poznan, Poland
}

Kardiochir Torakochir Pol 2019; 16 (4): 180-185

\begin{abstract}
Introduction: Lung cancer has been the most common cause of cancer deaths in the past few decades worldwide. In the differentiation of the histopathological types, two basic markers are currently used, which are napsin A and thyroid transcription factor-1 (TTF-1).

Aim: To assess the sensitivity of TTF-1, napsin A and combined use of both markers in detecting primary lung adenocarcinoma. The second aim was to examine the role of TTF- 1 and nap$\sin \mathrm{A}$ both alone and in combination as prognostic markers.

Material and methods: In the course of the study, patients' data were collected and histological specimens were evaluated using TTF-1 and napsin A as cancer markers.

Results: The sensitivities for TTF- 1 and napsin A when used separately were $74.58 \%$ and $49.15 \%$ respectively. When a panel of both TTF- 1 and napsin A was used the sensitivity increased to $79.17 \%$ as 38 out of 48 cases were positive for either or both of the immunohistochemical markers. The results for 1-, 3-, 4-year survival data were $87.9 \%, 70.7 \%$, 58.6\%, with TTF-1 positive patients having better survival.

Conclusions: We have shown that both TTF-1 and napsin A are sensitive markers of primary lung adenocarcinoma with TTF-1 being more sensitive. Sensitivity increases when both markers are used in combination.
\end{abstract}

Key words: TTF-1, napsin A, adenocarcinoma, prognostic value.

\section{Streszczenie}

Wprowadzenie: W ostatnich kilku dekadach rak płuca jest najczęstszą przyczyną zgonów z powodu nowotworu na świecie. W różnicowaniu typów histopatologicznych stosuje się obecnie dwa podstawowe markery - napsynę A oraz thyroid transcription factor-1 (TTF-1).

Cel: Ocena czułości TTF-1, napsyny A oraz kombinacji obu markerów w wykrywaniu pierwotnego gruczolakoraka płuc. Drugim celem było zbadanie roli TTF-1 i napsyny A odrębnie oraz w połączeniu jako markerów prognostycznych.

Materiat i metody: W trakcie badania zebrano dane pacjentów, a próbki histologiczne oceniono za pomocą TTF-1 i napsyny A jako markerów raka.

Wyniki: Czułość TTF-1 i napsyny A stosowanych odrębnie wyniosła odpowiednio 74,58\% i 49,15\%. Gdy zastosowano panel TTF-1 i napsyny A, czułość wzrosła do 79,17\% - 38 z 48 przypadków było dodatnich dla jednego lub obu markerów immunohistochemicznych. Odsetki rocznego, 3- oraz 4-letniego przeżycia wyniosły w tej grupie odpowiednio $87,9 \%, 70,7 \%$, $58,6 \%$, a pacjenci dodatni pod względem TTF-1 mieli lepsze przeżycie.

Wnioski: Zarówno TTF-1, jak i napsyna A są wrażliwymi markerami pierwotnego gruczolakoraka płuc, przy czym TTF-1 jest bardziej wrażliwy. Czułość wzrasta, gdy stosowana jest kombinacja obu makerów.

Słowa kluczowe: TTF-1, napsyna A, gruczolakorak, wartość prognostyczna.

\footnotetext{
Address for correspondence: Piotr J. Skrzypczak MD, Department of Thoracic Surgery, Wielkopolska Center of Pulmonology and Thoracic Surgery, Poznan University of Medical Sciences, 15 Poznańska St, 64-000 Kościan, Poland, phone: +48 661962 498,

e-mail: piotr.j.skrzypczak@gmail.com

Received: 26.08.2019, accepted: 13.10.2019.
} 


\section{Introduction}

Lung cancer is the most common malignancy in Poland. In recent years it was diagnosed in about 16000 men and about 6000 women a year. Out of all malignant neoplasms, lung cancer is the cause of the highest number of deaths among men and women [1]. Worldwide, lung cancer has been the most frequent malignant tumour and the most common cause of cancer-related deaths in the past few decades. In 2012, a total of 1.8 million new cases were diagnosed, accounting for almost $12.9 \%$ of all new cancer diagnoses [2].

About $95 \%$ of all lung cancers are of 4 histopathological types: adenocarcinoma (about 40\% - the most common type in the non-smoker group), squamous cell carcinoma (about 30\%), small cell carcinoma (about 15\%) and large cell carcinoma (about 10\%). Epidemiological data show that the proportion of glandular cancer is steadily increasing [1].

Early detection and accurate diagnosis of the histopathological type of lung cancer plays a crucial role in the therapeutic process. In the differential diagnosis, two immunohistochemical markers are currently employed - nap$\sin A$ and thyroid transcription factor-1 (TTF-1).

Napsin A, a novel aspartic proteinase of the pepsin family A, was first described in 1998 by Tatnell et al. [3, 4]. It is mostly expressed in type II pneumocytes, where it is associated with surfactant protein B maturation. Its expression in primary lung adenocarcinoma has been widely described and it is a frequently used marker in lung cancer differentiation [3, 5-7].

Thyroid transcription factor 1 (TTF-1), also known as thyroid-specific enhancer-binding protein, is physiologically expressed in thyroid, brain and lung tissue, where it regulates the expression of surfactant $A, B, C$ and Clara cell proteins. Similarly to napsin A, TTF-1 is also commonly employed in lung cancer differentiation $[3,8,9]$.

Both TTF-1 and napsin A are extremely useful tools in distinguishing primary and metastatic lung adenocarcinoma.

Although a considerable amount of literature, including two meta-analyses by Qian et al. and Berghmans et al., has been published on the prognostic role of TTF-1 in non-small cell carcinoma patients $[9,10]$, there is paucity of research on the prognostic role of napsin A in this group of patients and hence still much uncertainty exists about this relationship.

\section{Aim}

In this study, we aimed to assess: (1) the sensitivity of TTF-1, napsin A and combined use of both markers in detecting primary lung adenocarcinoma; and (2) the role of TTF-1 and napsin A both alone and in combination as prognostic markers in primary lung adenocarcinoma patients.

\section{Material and methods \\ Selection criteria, initial examinations, and follow-up}

From January 2012 to December 2012, 318 patients were operated on for lung cancer (mostly lung adenocarcinoma or squamous cell carcinoma). The decision of surgery was made on the basis of diagnostic imaging (CT scan, PET-CT scan), endoscopy (bronchofiberoscopy, autofluorescence bronchoscopy, endobronchial ultrasound-guided biopsy) and other examinations as needed ("blind" transbronchial biopsy, transthoracic needle aspiration biopsy). The cardiopulmonary system was evaluated using spirometry, diffus ing capacity of the lung for carbon monoxide (DLCO), capillary blood gas screening and electrocardiography (ECG). In some patients, a 6-minute walk test, stair climb test and additional cardiovascular examinations (exercise test, Holter monitoring, coronary angiography) were also performed. Doubtful cases were finally decided on the basis of the predicted post-operative value of the forced expiratory volume in $1 \mathrm{~s}\left(\mathrm{ppoFEV}_{1}\right)$ and predicted post-operative diffusing capacity of the lung for carbon monoxide (ppoDLCO) calculations.

After the surgery, the patients were consulted by an oncologist and depending on the staging of the tumor, according to the $7^{\text {th }}$ edition of the 2009 TNM classification, histopathological examination, the general condition of the patient and accompanying diseases, they were qualified for adjuvant chemo- and/or radiotherapy [11].

Of the initial cohort of 318 patients who were operated on, 59 were included in the study based on the following eligibility criteria: (1) histologically confirmed diagnosis of primary lung adenocarcinoma or its subtype/variant: lepidic, acinar, papillary, micropapillary, solid predominant with mucin production, mucinous, colloid, fetal or enteric; (2) immunohistochemically stained for TTF-1.

Patients' follow-up was based on the clinical data collected in the Thoracic Surgery Ward of Poznan University of Medical Sciences (data regarding surgery and control visits) and the Polish Group of Lung Cancer databases. The patients were followed up until $14^{\text {th }}$ August 2016 or death According to these data the 1-, 3- and 4-year survival rates were determined.

Prior to commencing the study, ethical clearance was sought from Poznan University of Medical Sciences Bioethics Commission.

\section{Immunohistochemical reaction for TTF-1}

The immunohistochemical reactions for TTF-1 were performed as part of routine diagnostics between January 2012 and December 2012.

Formalin-fixed, paraffin-embedded tissues were cut into $4 \mu \mathrm{m}$ sections which were then placed on FLEX IHC Microscope Slides (Dako, Agilent). The immunohistochemical reaction was carried out on the Autostainer Link 48 instrument (Dako, Agilent). Following epitope retrieval through the use of EnVision FLEX Targer Retrieval Solution, High $\mathrm{pH}$ (Dako, Agilent) for 20 minutes, the slides were incubated with a monoclonal mouse antibody against TTF-1 (clone SPT24, 1 : 200, Leica, Novocastra) for 30 minutes. EnVision FLEX+ Mouse Linker (Dako, Agilent) was used to enhance the quality of the reaction. The reaction was finally detected using EnVision FLEX Kit, High pH (Dako, Agilent). 
The slides were assessed by a specialist in clinical pathology (Katarzyna Iwanik - K.I., MD, Ph.D.). The presence of a brown colored reaction in the nuclei of cancer cells was considered positive. Lack thereof was interpreted as a negative immunohistochemical reaction.

\section{Immunohistochemical reaction for napsin A}

Formalin-fixed, paraffin-embedded tissue was cut into $4 \mu \mathrm{m}$ sections, which were then placed on SuperFrost Plus Adhesion Slides (Thermo Scientific). The slides were pretreated with Cell Conditioning Solution 1 (CC1, Ventana) for 30 minutes and subsequently incubated for 16 minutes with a monoclonal mouse antibody against napsin A (MRQ20 clone, Ventana) on the BechmarkXT instrument (Roche). The immunohistochemical reaction was finally detected using an ultraView Universal DAB Detection Kit (Ventana).

The slides were evaluated by a specialist in clinical pathology (K.I.). A brown colored reaction in the cytoplasm of cancer cells was considered positive. Lack thereof was interpreted as a negative immunohistochemical reaction.

\section{Statistical analysis}

Data management was performed in Open Office Calc 4.1.3. Descriptive statistics were carried out in Statistica v. 12 (StatSoft, Inc. (2014). Statistica (data analysis software system, version 12. www.statsoft.com). Kaplan-Meier estimator was used to assess the overall survival; the curves were then plotted and compared using the log-rank test

Table I. Clinical characteristics of patients included in the study

\begin{tabular}{lc} 
Variable & Number of patients \\
\hline Mender: & $38(64.41 \%)$ \\
\hline Memale & $21(35.59 \%)$ \\
\hline Age: & 62.42 \\
\hline Mean & 63.00 \\
\hline Median & $34-75$ \\
\hline Range & $40(18.64 \%)$ \\
\hline Surgical approach: & $11(67.80 \%)$ \\
\hline video-assisted thoracoscopy & $8(13.56 \%)$ \\
\hline thoracotomy & $3(5.08 \%)$ \\
\hline not applicable & $2(3.39 \%)$ \\
\hline Resection type: & $18(30.51 \%)$ \\
\hline Right pneumonectomy & $1(1.69 \%)$ \\
\hline Left pneumonectomy & $2(3.39 \%)$ \\
\hline Right upper lobectomy & $9(15.25 \%)$ \\
\hline Right middle lobectomy & $12(20.34 \%)$ \\
\hline Right lower lobectomy & $1(1.69 \%)$ \\
\hline Left upper lobectomy & $8(13.56 \%)$ \\
\hline Left lower lobectomy & \\
\hline Upper bilobectomy & \\
\hline Lower bilobectomy & \\
\hline Not applicable & \\
\hline
\end{tabular}

with statistical significance set at the $p=0.05$ level. The survival analysis was performed through the use of MedCalc 17.9.7.

\section{Results}

\section{Clinical data}

The analyzed groups did not differ significantly in age or sex. The clinical data are presented in Tables I and II.

The percentage of post-operative complications was $20.3 \%$. The most frequent postoperative complication was atrial fibrillation (10.3\%). The possible pre-operative occurrence of this complication was excluded by performing ECG before the surgery. The in-hospital mortality rate was $1.69 \%$ and there were no intraoperative deaths. The post-

Table II. T, N, M categories and stage

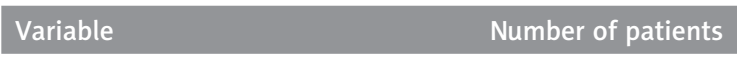

$\mathrm{T}:$

\begin{tabular}{lc}
\hline Tx & $0(0.00 \%)$ \\
\hline T0 & $0(0.00 \%)$ \\
\hline Tis & $0(0.00 \%)$ \\
\hline T1a & $4(6.78 \%)$ \\
\hline T1b & $4(6.78 \%)$ \\
\hline T2a & $20(33.90 \%)$ \\
\hline T2b & $13(22.03 \%)$ \\
\hline T4 & $6(10.17 \%)$ \\
\hline not applicable & $4(6.78 \%)$ \\
\hline
\end{tabular}

$\mathrm{N}$ :

\begin{tabular}{lc}
\hline Nx & $0(0.00 \%)$ \\
\hline N0 1 & $29(49.15 \%)$ \\
\hline N2 & $13(22.03 \%)$ \\
\hline N3 & $9(15.25 \%)$ \\
\hline not applicable & $0(0.00 \%)$ \\
\hline M0 & $8(13.56 \%)$ \\
\hline M1a & $49(83.05 \%)$ \\
\hline M1b & $1(1.69 \%)$ \\
\hline not applicable & $1(1.69 \%)$ \\
\hline Stage: & $8(13.56 \%)$ \\
\hline Occult carcinoma & $0(0.00 \%)$ \\
\hline 0 & $0(0.00 \%)$ \\
\hline IA & $6(10.17 \%)$ \\
\hline IB & $10(16.95 \%)$ \\
\hline IIA & $14(23.73 \%)$ \\
\hline IIB & $7(11.86 \%)$ \\
\hline IIIA & $11(18.64 \%)$ \\
\hline IIIB & $1(1.69 \%)$ \\
\hline IV & $2(3.39 \%)$ \\
\hline Not applicable & $8(13.56 \%)$ \\
\hline
\end{tabular}


Table III. Number of patients expressing TTF-1, napsin A or both

\begin{tabular}{lccc} 
Parameter & Napsin A (-) & Napsin A (+) & Total \\
TTF-1 (-) & $10(20.83 \%)$ & $3(6.25 \%)$ & $13(27.08 \%)$ \\
\hline TTF-1 (+) & $9(18.75 \%)$ & $26(54.17 \%)$ & $35(72.92 \%)$ \\
\hline Total & $19(39.58 \%)$ & $29(60.42 \%)$ & $48(100.00 \%)$ \\
\hline
\end{tabular}

Table IV. Number of patients expressing either TTF-1, napsin A or both along with the sensitivity of a panel of both markers

\begin{tabular}{lc} 
Parameter & $\begin{array}{c}\text { Number of cases } \\
\text { (percentage out of total number of cases) }\end{array}$ \\
\hline TTF-1 (-) Napsin A (+) & $3(6.25 \%)$ \\
\hline TTF-1 (+) Napsin A (-) & $9(18.75 \%)$ \\
\hline TTF-1 (+) Napsin A (+) & $26(54.17 \%)$ \\
\hline Total & $38(79.17 \%)$ \\
\hline
\end{tabular}

operative period ranged from 4 to 22 days with a mean of 8 days.

\section{Sensitivity of TTF-1 and napsin A in primary adenocarcinoma of the lung}

Immunohistochemical expression of TTF-1 was evaluated in all of the 59 cases included in the study. Of those, $44(74.58 \%)$ showed a brown colored reaction in the nucleus of cancer cells and were therefore considered positive, while lack thereof was noted in 15 (25.42\%) cases. However, only 48 cases were assessed for napsin A as in 11 cases the appropriate formalin-fixed paraffin-embedded (FFPE) tissues were either lacking or they did not contain enough stainable tissue for evaluation of this particular marker. Of the available cases, 29 (49.15\%) were positive for napsin A and 19 (32.20\%) were negative. Hence the sensitivities for TTF-1 and napsin A, when used separately, were $74.58 \%$ and $49.15 \%$ respectively.

With a panel of both TTF-1 and napsin A the sensitivity increased to $79.17 \%$ as 38 out of 48 cases were positive for either or both of the immunohistochemical markers. As shown in Table III, 10 (20.83\%) cases were negative for both TTF-1 and napsin A, 3 (6.25\%) were positive for napsin A but negative for TTF-1, 9 (18.75\%) were positive for TTF-1 but negative for napsin A, while 26 (54.17\%) showed positive immunohistochemical reaction for both TTF-1 and napsin A (Table IV).

\section{Survival analysis}

According to the aforementioned methodology, the 1-, 3- and 4- year survival rates were determined. The results for 1-, 3-, 4- year survival data were $87.9 \%, 70.7 \%$, 58.6\% respectively.

Kaplan-Meier survival analysis was performed for TTF-1, napsin A and for a panel of both TTF-1 and napsin A. There was a statistically significant difference $(p=0.0344)$ in overall survival between TTF-1 positive and TTF-1 negative patients, with TTF-1 positive patients having a better overall survival (Figure 1). Interestingly, no statistically significant difference in overall survival was noted $(p=0.8814)$

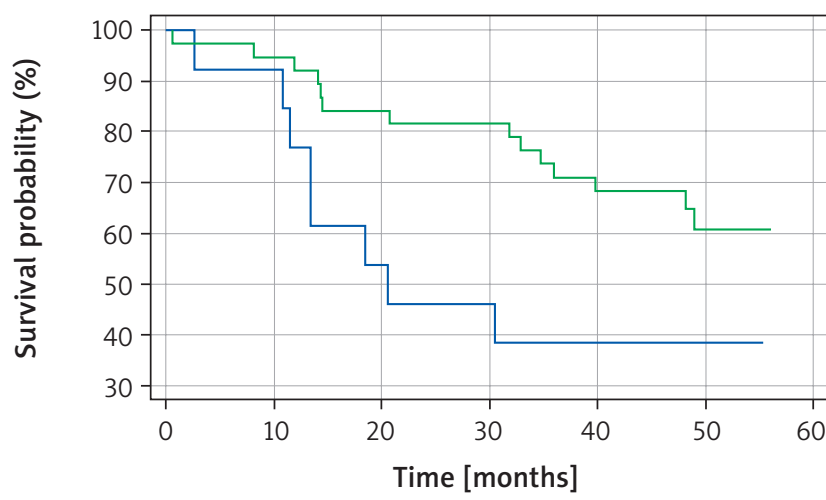

Figure 1. Kaplan-Meier survival curve for TTF-1 positive (green line) and TTF-1 negative (blue line) patients

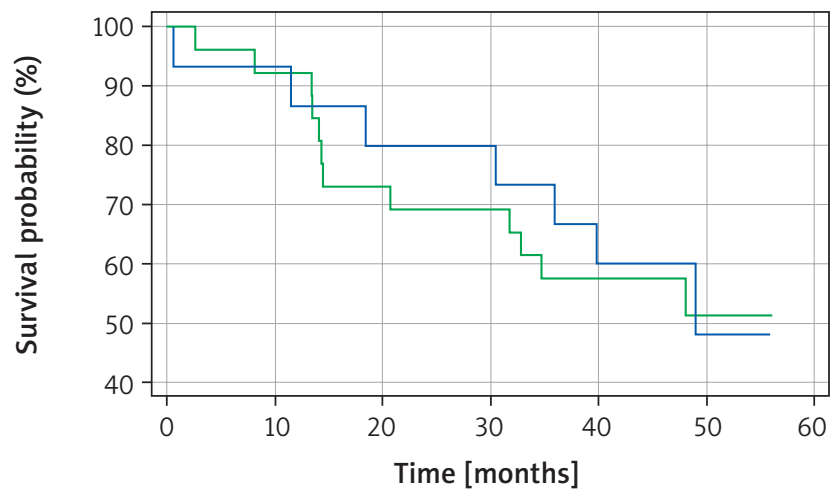

Figure 2. Kaplan-Meier survival curve for napsin A positive (green line) and napsin A negative (blue line) patients

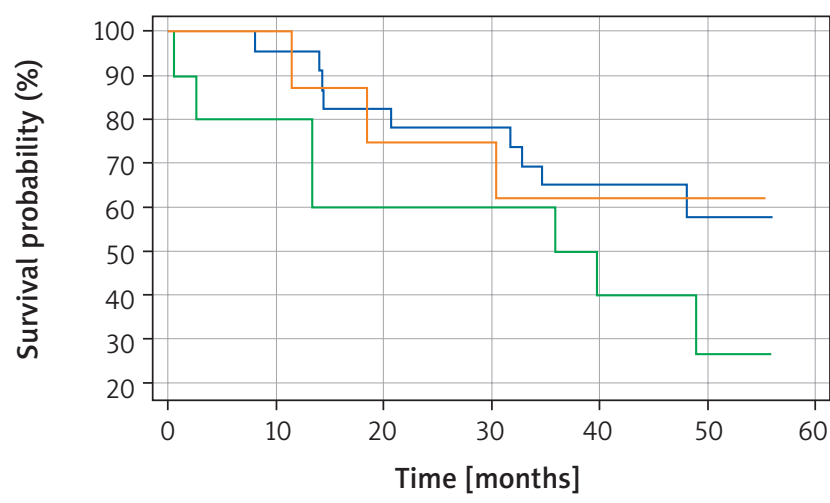

Figure 3. Kaplan-Meier survival curves for TTF-1 and napsin A positive patients (blue line), TTF-1 and napsin A negative patients (orange line), and patients positive for either TTF-1 or napsin A (green line)

between napsin A positive and negative patients (Figure 2). Similarly, there was no statistically significant difference in overall survival ( $p=0.2196)$ when cases were compared in the following groups: [1] positive for both TTF-1 and napsin, [2] positive for either TTF-1 or napsin, [3] negative for both TTF-1 and napsin A (Figure 3).

\section{Discussion}

TTF-1 and napsin A are commonly employed antibodies in immunohistochemical differentiation between primary 
and metastatic lung cancers. In one of the largest studies to date of 1674 cases of lung adenocarcinoma, by Bradley et al. [6], both napsin A and TTF-1 were found to be sensitive markers of primary adenocarcinoma of the lung with sensitivities of $87.0 \%$ and $64.0 \%$ respectively. In this study, napsin A was described as a more sensitive marker than TTF-1 in detecting primary lung adenocarcinoma. This is in contrast to our study in which TTF-1 was found to be more sensitive (74.58\%) than napsin A (49.15\%) in detecting primary lung adenocarcinomas. However, according to El-Maqsoud et al. [12] napsin A expression varies with studies and may be as low as $48.5 \%$ in non-small cell lung carcinomas. Similarly, following El-Maqsoud et al. [12], TTF-1 expression in different publications is not consistent, with values as low as $39 \%$ for lung adenocarcinomas. As shown in our study, combining the use of napsin A and TTF-1 increases the sensitivity of detection of primary adenocarcinoma to $79.17 \%$ as it accounts for cases being positive for either or both of the immunohistochemical markers. Therefore, we advocate a panel containing at least TTF-1 and napsin A when diagnosing primary adenocarcinomas of the lung.

To date, two meta-analyses have been performed to analyse the prognostic value of TTF-1 in non-small cell lung cancer. The first one, by Berghmans et al. [10] in 2006, evaluated 10 studies published from 1999 to 2005 with 1101 patients in total. At that time, four out of the ten eligible papers showed that patients with a positive immunohistochemical reaction for TTF-1 in non-small cell lung cancer (NSCLC) have better overall survival but only one showed that a negative immunohistochemical reaction for TTF-1 may be related to poorer survival. The five remaining studies showed no statistically significant difference between TTF-1 positive and TTF-1 negative patients. The combined hazard ratios calculated based on only eight papers, as not all papers had enough data for the meta-analysis, was 0.64 , which indicated that TTF-1 positive patients with NSCLC had better overall survival. However, in this meta-analysis only four studies focused exclusively on adenocarcinoma of the lung; out of those, for two the survival analysis did not yield any statistically significant differences, and for the other two better survival was observed in TTF-1 positive patients.

In 2015, another meta-analysis, by Qian et al. [9], was published that covered 17 studies from 1999 to 2012 with a total of 2235 patients. The combined HR for this study was 0.49 , and, similarly to the previous meta-analysis, it indicated that TTF-1 positive patients with NSCLC have better overall survival. This study included a greater number of studies with solely adenocarcinoma patients (that is 11 out of 17). The combined HR for the adenocarcinoma subgroup was 0.45 , which was consistent with the general conclusion of the study.

In the context of the aforementioned papers, our study also showed a statistically significant difference in survival between TTF-1 positive and TTF-1 negative patients $(p=0.0344)$. However, recently, a study published by Zhou et al. [13] analysed the difference in survival between 2687
TTF-1 positive and 126 TTF-1 negative patients with stage I adenocarcinoma of the lung. They did not find a statistically significant difference in overall survival between TTF-1 positive and TTF-1 negative patients.

Although the prognostic role of TTF-1 has been studied quite extensively, we have been able to identify only three papers, by Lee et al., Ma et al. and Piljić Burazer et al., that evaluated napsin A as a prognostic factor in patients with a histopathological diagnosis of adenocarcinoma of the lung [14-16]. All three studies showed that napsin A positive patients have statistically significant better overall survival than napsin A negative patients. This is in contrast to our study, which shows that there is no statistically significant difference between the two groups of patients. However, we have been able to assess only 48 cases for napsin A as in the remaining 11 cases the appropriate FFPE tissues were either lacking or they did not contain enough stainable tissue for evaluation of this marker. Hence, it is possible that lack of statistical significance may be attributed to small sample size and further studies are needed to evaluate the relationship between napsin A expression and overall survival.

Similarly to napsin A, there remains a paucity of evidence on the prognostic role of the combined use of both markers - TTF-1 and napsin A. We have been able to identify only one study that analysed the association between combined TTF-1 and napsin A expression and the overall survival. In the study, published in 2015, Ma et al. investigated the relationship between high expression of TTF-1 and napsin A, partial expression of TTF-1 and napsin A, and low expression of TTF-1 and napsin A and overall survival [15]. They found that patients positive for both TTF-1 and napsin A have statistically significant better overall survival. In our study, we also aimed to investigate the association between the combined use of TTF-1 and napsin A and overall survival. In contrast to the study by Ma et al., we divided our patients into three groups: patients positive for both markers, patients positive for either of the markers and patients negative for both markers. We did not find any statistically significant difference $(p=0.2196)$ in overall survival among these groups of patients.

\section{Conclusions}

We have demonstrated that both TTF-1 and napsin A are sensitive markers of primary lung adenocarcinoma with TTF-1 being more sensitive and with the sensitivity increasing when both markers are used in combination. What is more, our study supports the already gathered evidence on the positive prognostic role of TTF-1 in lung adenocarcinoma. However, more studies are needed to elucidate the role of napsin A alone and in combination with TTF-1 as a prognostic marker.

\section{Acknowledgments}

This work was supported by the Students' Scientific Society, Poznan University of Medical Sciences (Grant no. 201). 


\section{Disclosure}

The authors report no conflict of interest.

\section{References}

1. Krzakowski M, Warzocha K. Zalecenia postępowania diagnostyczno-terapeutycznego w nowotworach złośliwych. Via Medica, Gdańsk 2013.

2. Wong MCS, Lao XQ, Ho KF, Goggins WB, Shelly LA. Incidence and mortality of lung cancer: global trends and association with socioeconomic status. Sci Rep 2017; 7: 14300.

3. Tatnell PJ, Powell DJ, Hill J, Smith TS, Tew DG, Kay J. Napsins: new human aspartic proteinases. FEBS Lett 1998; 441: 43-48.

4. Stoll LM, Johnson MW, Gabrielson E, Askin F, Clark DP, Li QK. The utility of napsin-A in the identification of primary and metastatic lung adenocarcinoma among cytologically poorly differentiated carcinomas. Cancer Cytopathol 2010; 118: 441-449.

5. Ueno T, Linder S, Elmberger G. Aspartic proteinase napsin is a useful marker for diagnosis of primary lung adenocarcinoma. Br J Cancer 2003; 88: 12291233.

6. Turner BM, Cagle PT, Sainz IM, Fukuoka J, Shen SS, Jagirdar J. Napsin A, a new marker for lung adenocarcinoma, is complementary and more sensitive and specific than thyroid transcription factor 1 in the differential diagnosis of primary pulmonary carcinoma: evaluation of 1674 cases by tissue microarray. Arch Pathol Lab Med 2012; 136: 163-171.

7. Zhang P, Han YP, Huang L, Li Q, Ma DL. Value of napsin A and thyroid transcription factor-1 in the identification of primary lung adenocarcinoma. Oncol Lett 2010; 1: 899-903.
8. Bishop JA, Sharma R, Illei PB. Napsin A and thyroid transcription factor-1 expression in carcinomas of the lung, breast, pancreas, colon, kidney, thyroid, and malignant mesothelioma. Hum Pathol 2010; 41: 20-25.

9. Qian H, Xu TS, Cai XQ, Ji TL, Guo HX. Prognostic value of TTF-1 expression in patients with non-small cell lung cancer: a meta-analysis. Clin Chim Acta 2015; 451: 208-214.

10. Berghmans T, Paesmans M, Mascaux C, Martin B, Meert AP, Haller A, Lafitte JJ, Sculier JP. Thyroid transcription factor 1-a new prognostic factor in lung cancer: a meta-analysis. Ann Oncol 2006; 17: 1673-1676.

11. Sobin LH, Gospodarowicz MK, Wittekind C. TNM Classification of Malignant Tumours. $7^{\text {th }}$ edn. John Wiley \& Sons, Ltd. Publication 2009.

12. El-Maqsoud NM, Tawfiek ER, Abdelmeged A, Rahman MF, Moustafa AA. The diagnostic utility of the triple markers Napsin A, TTF-1, and PAX8 in differentiating between primary and metastatic lung carcinomas. Tumour Biol 2016; 37: 3123-3134.

13. Zhou C, Zhao J, Shao J, Li W. Prognostic relevance of TTF-1 expression in stage I adenocarcinoma. Oncotarget 2017; 8: 107462-107468.

14. Lee JG, Kim S, Shim HS. Napsin A is an independent prognostic factor in surgically resected adenocarcinoma of the lung. Lung Cancer 2012; 77: 156-161.

15. Ma Y, Fan M, Dai L, Kang X, Liu Y, Sun Y, Yan W, Liang Z, Xiong H, Chen K. The expression of TTF-1 and Napsin A in early-stage lung adenocarcinoma correlates with the results of surgical treatment. Tumour Biol 2015; 36: 8085-8092.

16. Piljić Burazer M, Mladinov S, Ćapkun V, Kuret S, Glavina Durdov M. The utility of thyroid transcription factor 1 (TTF-1), Napsin A, excision repair cross-complementing 1 (ERCC1), anaplastic lymphoma kinase (ALK) and the epidermal growth factor receptor (EGFR) expression in small biopsy in prognosis of patients with lung adenocarcinoma - a retrograde single-center study from Croatia. Med Sci Monit 2017; 23: 489-497. 